\title{
Validation of a quick and simple chromatographic method for simultaneous quantification of sertraline, escitalopram, risperidone and paliperidone levels in the human plasma
}

\author{
Aleksandra Jeremić ${ }^{1 *}$, Filip Milosavljević ${ }^{1 *}$, Sandra Vladimirov ${ }^{2}$, \\ Bojan Batinić ${ }^{1}$, Bojan Marković ${ }^{3}$, Marin Jukićc ${ }^{1,4 \#}$ \\ ${ }^{1}$ University of Belgrade - Faculty of Pharmacy, Department of Physiology, \\ Belgrade, Serbia \\ ${ }^{2}$ University of Belgrade - Faculty of Pharmacy, Department of Medical Biochemistry, \\ Belgrade, Serbia \\ ${ }^{3}$ University of Belgrade - Faculty of Pharmacy, Department of Pharmaceutical \\ Chemistry, Belgrade, Serbia \\ ${ }^{4}$ Pharmacogenetics section, Department of Physiology and Pharmacology, Karolinska \\ Institutet, Solna, Sweden \\ * These authors contributed equally to the manuscript and share the first authorship \\ ${ }^{\#}$ Corresponding author: Marin Jukić, \\ E-mail: marin.jukic@pharmacy.bg.ac.rs or marin.jukic@ki.se
}

\begin{abstract}
Simultaneous quantification of multiple psychiatric drugs is important for the therapeutic drug monitoring of psychiatric patients. In addition, it would be highly advantageous if the method could be simple, straightforward, and not time-consuming. A $200 \mu 1$ plasma sample was deproteinized, drugs were separated by a ZORBAX Eclipse XDB-Phenyl column with the mobile phase composed of acetonitrile and $0.1 \%$ formic acid in water $(60: 40, \mathrm{v} / \mathrm{v})$, and recorded in the MRM mode by using a positive electrospray source with tandem mass spectrometry detection. The dynamic range was $2-256 \mathrm{ng} / \mathrm{ml}$ for all the analyzed drugs, except escitalopram $(8-256 \mathrm{ng} / \mathrm{ml})$. Quality control samples were prepared in quintuplicates in three relevant concentrations for each drug. Coefficients of determination $\left(\mathrm{R}^{2}\right)$ were higher than 0.99 , while the relative difference between nominal and measured concentrations (RE) and CV were lower than $15 \%$ for all targets. High performance liquid chromatography coupled with the mass detector (HPLC-MS/MS) method for simultaneous determination of sertraline, escitalopram, risperidone
\end{abstract}


and paliperidone in human plasma was validated with respect to selectivity, linearity, accuracy, precision, matrix effect and stability. This method has significant advantages in terms of low sample volume $(200 \mu \mathrm{l})$, short preparation time (3 hours) and short runtime per sample (4 minutes).

Keywords: sertraline, escitalopram, risperidone, paliperidone, HPLC-MS/MS

doi.org/10.5937/arhfarm71-31163

\section{INTRODUCTION}

Since approximately half the population meets the diagnostic criterion for a psychiatric disorder at one point during lifetime (1), it is almost impossible to overstate the significance of improving mental health. However, since the development of successful and applicable psychiatric drugs has been at a near standstill for a very long time, it is of utmost importance to utilize the psychiatric drugs currently available on the market as effectively as possible. One important aspect is precise dosing; patients who are underexposed to the drug are at risk of insufficient response, whereas overexposure may lead to dose-dependent side effects $(2,3)$. Due to the existence of inter-individual differences in drug metabolism (4), the dose required to achieve optimal blood levels of antidepressants and antipsychotics varies substantially between patients. Consequently, population-based dosing results in a significant proportion of patients who either are under- or over-exposed. The therapeutic window is relatively well-defined by the recently published consensus guidelines for the therapeutic drug monitoring (TDM) (5), based on positron emission tomography, pharmacokinetic and clinical studies. Because of the importance of appropriate exposure to psychiatric drugs, methods for determining drug plasma levels have been advanced by analytical chemists, with the aim of being able to provide reliable information about drug exposure to clinicians. It is crucial for a method to be correct, precise, and sensitive; however, from the pragmatic point of view it is also very important that the method should be quick, straightforward, and capable of measuring plasma levels of multiple drugs, as polypharmacy is highly prevalent among psychiatric patients. Our recently published reports demonstrate the usefulness of measuring plasma levels of escitalopram (6), sertraline (7), and risperidone (8).

Over the last two decades, numerous reports related to the quantification of antidepressants and antipsychotics in the serum have been published. Most of them utilize HPLC with ultra-violet or mass spectrometric detection, resulting in runtimes from 3.5 to 20 min (9-12.) The majority applies time-consuming and expensive sample preparation such as solid phase extraction and liquid-liquid extraction. Kirchherr and Kuhn-Velten (10) presented a method capable of measuring 48 antidepressants and antipsychotics by the precipitation of serum. It encompasses all the substances of interest for this report. 
The method uses structural analogs for quantification, a large column diameter of 4.6 $\mathrm{mm}$, and a high flow rate. The runtime was $8 \mathrm{~min}$. Some of the compounds, including one of the internal standards, eluted very early, increasing the risk of ion suppression. This report summarizes the outcome of our effort to develop a quick and adequate way to measure the plasma levels of these three drugs and paliperidone from a single sample by using high performance liquid chromatography coupled with a tandem mass detector (HPLC-MS/MS). The method applies fast and simple preparation of human plasma and has a total runtime of $4 \mathrm{~min}$, including the injection cycle.

In this method, thioridazine was used as the internal standard; it is noteworthy that in 2012 the clinical use of thioridazine was discontinued in Serbia, which means that local patients are never treated with thioridazine and exposed to this drug. However, if there were any chance that a patient had been exposed to thioridazine, an alternative compound would need to be used as the internal standard.

\section{MATERIAL AND METHOD}

\section{Chemicals and reagents}

Analytical standards sertraline hydrochloride, citalopram hydrobromide, risperidone, and 9-hydroxyrisperidone/paliperidone of analytical purity were supplied by the Cerilliant Corporation (USA), whereas the internal standard (IS) - thioridazine of pharmaceutical purity ( $>98 \%$ ), was purchased from Sigma-Aldrich (Germany). Methanol was supplied by Avantor - Macron (Center Valley, PA, USA) 3004-25. Formic acid and acetonitrile of HPLC grade were purchased from Fisher Scientific (Waltham, USA). Water was deionized and filtered through a $0.22 \mu \mathrm{m}$ filter, prior to the liquid chromatographic procedure.

\section{Standard stock solutions, calibration standards and quality control sample preparation}

All standard stock (Ss) solutions had the concentration of $1,000,000 \mathrm{ng} / \mathrm{ml}$ as a free base. Working stock solutions of escitalopram, sertraline, risperidone and paliperidone standards were prepared in the concentrations of 10,000 ng/ml (Wss) and 40,000 ng/ml (Wssx4) in methanol as free forms. All stock and working stock standard solutions were stored in the freezer $\left(-20^{\circ} \mathrm{C}\right)$.

Calibration standards (Cs) were prepared fresh by first preparing the most concentrated solution containing $5,120 \mathrm{ng} / \mathrm{ml}$ of all four drugs (using $32 \mu \mathrm{l}$ of each WSSx 4 solutions and $122 \mu 1$ of methanol), and then by its two-fold serial dilution with the same volume of methanol. Final concentrations of drugs in these Cs solutions are provided in Figure 1. Ten $\mu \mathrm{l}$ of each Cs solution were added to the $1.5 \mathrm{ml}$ tubes and evaporated to dryness under a stream of nitrogen gas (ReactiVAP evaporator system, Thermo Fisher Scientific) and $200 \mu 1$ of blank human drug-free plasma was added into every evaporated sample, followed by a 2-minute vortex mixing in order to prepare standard solutions in the biological matrix. The resulting plasma concentrations (Figure 
1) encompass the concentration range that can be observed in treated patients. The lower concentration levels of the analytes were set at the lower limit of quantification (LLOQ) of the proposed method. The LLOQ for sertraline, risperidone and paliperidone was 2 $\mathrm{ng} / \mathrm{ml}$, and for escitalopram was $8 \mathrm{ng} / \mathrm{ml}$.

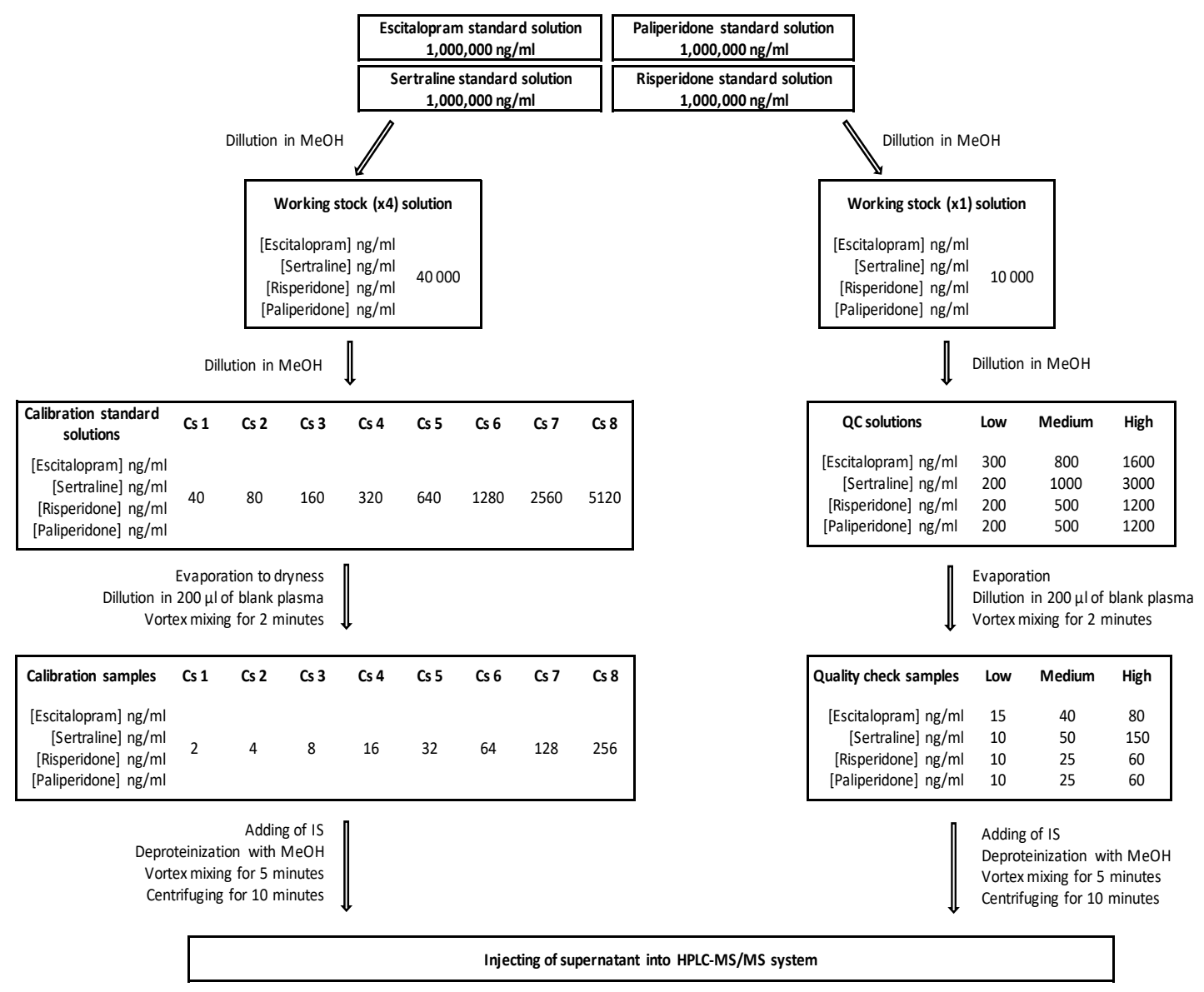

Figure 1. Schematic presentation of sample preparation for simultaneous Quantification of sertraline, escitalopram, risperidone and paliperidone.

All concentrations are in $\mathbf{n g} / \mathrm{ml}$

Slika 1. Šematska prezentacija pripreme uzorka za simultanu kvantifikaciju sertralina, escitaloprama, risperidona i paliperidona. Sve koncentracije su izražene u ng/ml

QC solutions were prepared by the dilution of Wss in methanol, from which QC samples were prepared the same way as Cs samples. Three levels of combined quality control (QC) samples were used with final analyte concentrations in plasma provided in Figure 1. These values were selected to mimic the expected patient drug exposure when the exposure is relatively low, optimal, or relatively high. 


\section{Internal standard working solution preparation}

Since deproteinization of samples can lead to unpredictable loss of analytes in the sample, thioridazine was used as an IS. Wss of thioridazine $(20,000 \mathrm{ng} / \mathrm{ml})$ was prepared from thioridazine Ss solutions and methanol in the ratio of 1:50. Thioridazine is a substance that possesses a similar chemical structure to the analyzed drugs, with the retention time and the characteristics during deproteinization also being similar. By adding a fixed, known amount of the IS to all the analyzed samples, possible loss of analytes, which may occur during deproteinization, can be quantified and corrected for. Also, the IS concentration represented an indicator of the drug concentration, based on the comparisons of the areas under the peaks of the chromatogram. Ten $\mu 1$ of IS working solution $(20,000 \mathrm{ng} / \mathrm{ml})$ was added to each tube containing $200 \mu 1$ plasma.

\section{Sample pretreatment}

QC samples and calibration standard were prepared using the protein precipitation technique. Each of the three levels QC samples was prepared in quintuplicate, whereas Cs samples had one replicate. First, after a 2-minute vortexing, a $600 \mu 1$ methanol was added to standards and QC samples to precipitate the plasma proteins, which are known to interfere with the HPLC-MS/MS method. Next, the tubes were vortex-mixed for $5 \mathrm{~min}$ and centrifuged at $15,500 \mathrm{G}$ for $10 \mathrm{~min}$ at $4^{\circ} \mathrm{C}$. Proteins were precipitated during the vortexing, and then settled to the bottom during centrifugation. A 400-600 $\mu 1$ aliquot of the supernatant was transferred to clean autosampler vials and was subsequently injected into the HPLC-MS/MS system (13). The complete sample preparation method is shown in Figure 1.

\section{Liquid chromatography/mass spectrometry}

Liquid chromatography (LC) was performed on an Agilent Infinity 1290 HPLC system (Agilent Technologies, Inc., USA) coupled with an Agilent 6420 triple quadrupole mass spectrometer (Agilent Technologies, Inc., USA). The separation was carried out at $40^{\circ} \mathrm{C}$ using a ZORBAX Eclipse XDB-Phenyl column $(50 \mathrm{~mm} \times 2.1 \mathrm{~mm}, 5 \mu \mathrm{m}$; Agilent Technologies, Inc., USA). The mobile phase, consisting of acetonitrile- $0,1 \%$ formic acid in water $(60: 40, \mathrm{v} / \mathrm{v})$, was set at a flow rate of $0.3 \mathrm{ml} / \mathrm{min}$. The process of separation was conducted under isocratic conditions. Target drugs were detected using an electrospray ion source (ESI) operated in a multiple reaction monitoring (MRM) mode. The ESI source parameters were as follows: nitrogen drying-gas, gas flow rate of $61 / \mathrm{min}$, gas temperature of $300{ }^{\circ} \mathrm{C}$, capillary voltage of $4000 \mathrm{~V}$, nebulizer pressure of $15 \mathrm{psi}$. MRM in positive ionization mode was used to quantify all targets. The monitored pseudomolecular ions $[\mathrm{M}+\mathrm{H}]^{+}$are presented in Table I. Mass spectrometry (MS) data were processed using the MassHunter software (Agilent Technologies, Inc., USA). 
Table I MRM transitions and conditions for the measurement of target compounds

Tabela I MRM tranzicija i uslovi merenja za supstance od interesa

\begin{tabular}{|c|c|c|c|c|}
\hline $\begin{array}{c}\text { Name of } \\
\text { compound }\end{array}$ & $\begin{array}{c}\text { Precursor } \\
\text { ion } m / z\end{array}$ & $\begin{array}{c}\text { Product } \\
\text { ion } m / z\end{array}$ & $\begin{array}{c}\text { Fragmentor } \\
\text { voltage [V] }\end{array}$ & $\begin{array}{c}\text { Collision } \\
\text { energy [eV] }\end{array}$ \\
\hline Escitalopram & 325.2 & 109 & 135 & 50 \\
\hline Sertraline & 306 & 159 & 75 & 20 \\
\hline Risperidone & 411.1 & 191.1 & 170 & 24 \\
\hline Paliperidone & 427.11 & 207.1 & 170 & 24 \\
\hline Thioridazine & 371 & 167 & 145 & 88 \\
\hline
\end{tabular}

\section{Method validation procedure}

The selectivity, lower limit of quantification, calibration curve performance, accuracy, precision, matrix effects, and stability were evaluated based on the HPLC-MS readouts. First, calibration curves were calculated based on the range of $2-256 \mathrm{ng} / \mathrm{ml}$ for all the analyzed drugs, except escitalopram, for which the range was $8-256 \mathrm{ng} / \mathrm{ml}$. This was done by determining the best fit of analyte peak area / IS peak area(y) vs nominal concentration of drug in Cs (x). Linearity was evaluated based on the coefficient of determination, where the $\mathrm{R}^{2}$ value of 0.99 or higher was considered satisfactory. Concentrations of QC samples were calculated using the equation derived from the calibration curve. Precision and accuracy were evaluated by assaying five replicates of each of the spiked QCs. This was done at low, medium and high concentrations. The precision was expressed as the coefficient of variation $(\mathrm{CV})$, where the $\mathrm{CV}$ value lower than $15 \%$ was considered satisfactory. Accuracy was calculated as the percent error in the determined mean concentration, relative to the nominal concentrations (RE), where RE value lower than $15 \%$ was considered satisfactory. The matrix effect was investigated by comparing the deproteinized samples of blank plasma from six different drug-free volunteers spiked with low and high concentrations of QC with the direct injection of mobile phase spiked with the analytes. Stability under the experimental condition was investigated at three levels of QC. The stability of the short-term stored analytes was evaluated by testing them after being protein-precipitated and stored for $24 \mathrm{~h}$ at room temperature. The long-term stability was examined for 40 days at $-70^{\circ} \mathrm{C}$. Freeze/thaw stability testing was determined after three freeze (at $-70^{\circ} \mathrm{C}$ ) thaw (at room temperature) cycles. For specificity, post-column infusion of analytes and injection of extracted blank samples from six different donors was performed and evaluated.

The proposed analytical method was tested on representative plasma samples collected from 20 patients from Institute of Mental Health in Belgrade. Blood samples (3 $\mathrm{mL}$ ) from 20 patients were collected after two weeks of daily usage of $10 \mathrm{mg}$ of escitalopram. Plasma was separated by centrifugation at $765 \times \mathrm{g}$ for $10 \mathrm{~min}$ at $4^{\circ} \mathrm{C}$ and stored at $-70^{\circ} \mathrm{C}$ until analyzed. 


\section{RESULTS AND DISCUSSION}

The method was validated according to the EMEA/CHMP/EWP/192217/2009 Rev. 1 Guideline on bioanalytical method validation with respect to selectivity, linearity, accuracy, precision, matrix effect and stability. Ion chromatograms of samples are depicted in Figure 2 and they demonstrate very good separation of all the analyzed drugs and the internal standard. Ion chromatograms from six blank samples (non-spiked blank plasma), a zero sample (only spiked with IS), a blank sample spiked at LOQ of two analytes and a sample after administration showed no significant interference peak at the retention time of sertraline, escitalopram, risperidone and paliperidone. The calibration curves demonstrated satisfactory linearity for all four drugs with coefficients of determination $\left(\mathrm{R}^{2}\right)$ larger than 0.99. The intercepts, slopes and coefficients of determination are presented in Figure 3. Precision was satisfactory for all three QC samples analyzed for all four drugs, with all coefficients of variance (CV) lower than $15 \%$. Accuracy was satisfactory for all three QC samples analyzed for all four drugs, with all relative errors (RE) lower than $15 \%$. The $\mathrm{CV}$ and $\mathrm{RV}$ values for individual drugs are presented in Table II. Sertraline, escitalopram, risperidone and paliperidone were proved to be stable in processed samples at room temperature for at least $24 \mathrm{~h}$, for 40 days in plasma at $-70^{\circ} \mathrm{C}$ and in plasma after three freeze and thaw cycles. These results indicate that the method was reliable and robust within the analytical range. 


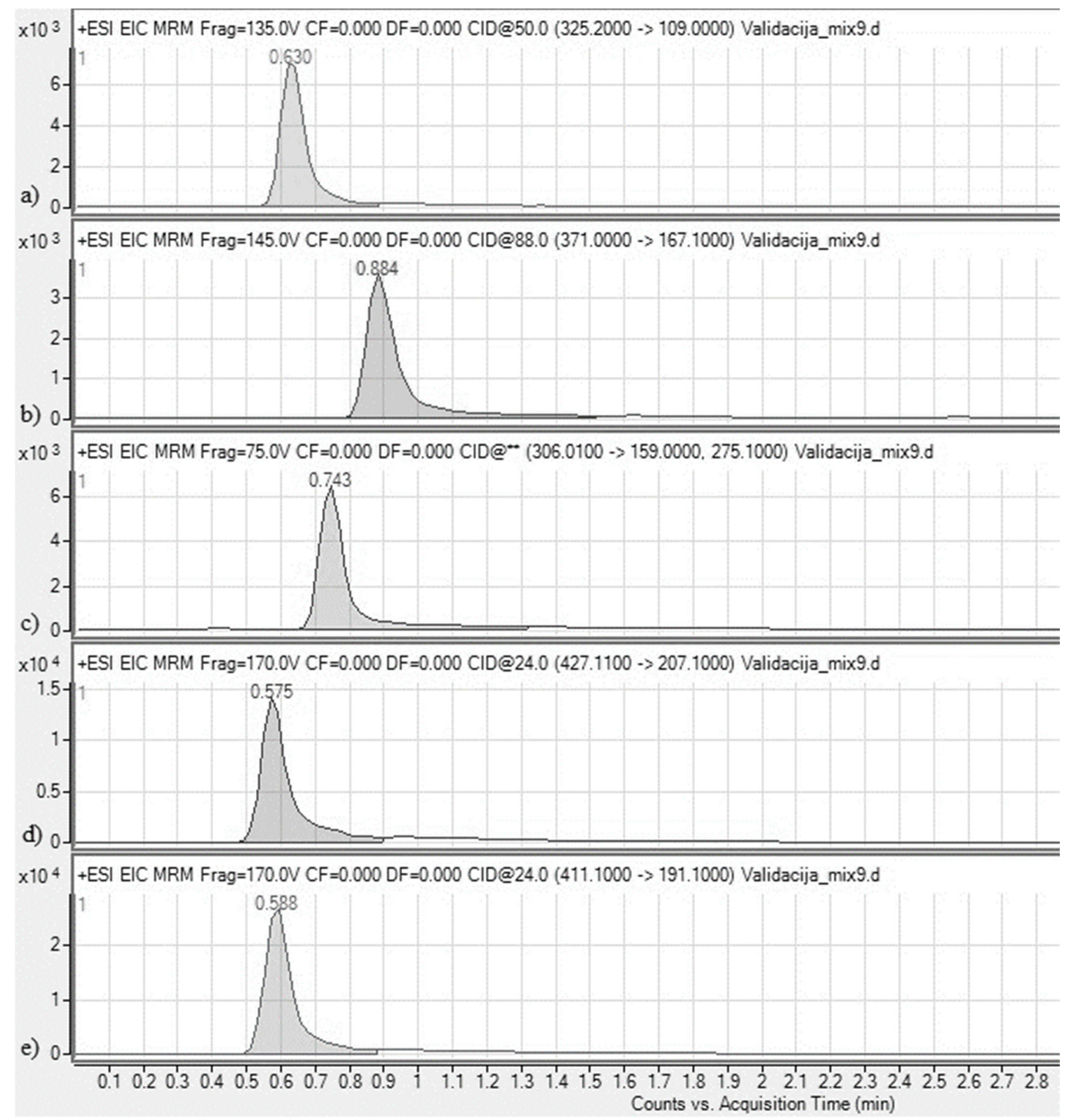

Figure 2. MRM chromatograms of analytes and IS: a) escitalopram (RT=0,630 min) b) thioridazine $(\mathrm{RT}=\mathbf{0 , 8 8 4} \mathrm{min}) \mathrm{c})$ sertraline $(\mathrm{RT}=\mathbf{0 , 7 4 3} \mathrm{min})$ d) paliperidone $(\mathrm{RT}=\mathbf{0 , 5 7 5} \mathrm{min})$ e) risperidone $(\mathrm{RT}=\mathbf{0 , 5 8 8} \mathrm{min})$

Slika 2. MRM hromatogrami analita i internog standarda: a) escitalopram $(\mathrm{RT}=\mathbf{0 , 6 3 0} \mathrm{min}) \mathrm{b}$ ) tioridazin $(\mathrm{RT}=\mathbf{0 , 8 8 4} \mathrm{min}) \mathrm{c})$ sertralin $(\mathrm{RT}=\mathbf{0 , 7 4 3} \mathrm{min})$ d) paliperidon $(\mathrm{RT}=\mathbf{0 , 5 7 5} \mathrm{min})$ e) risperidon $(\mathrm{RT}=\mathbf{0 , 5 8 8} \mathrm{min})$ 


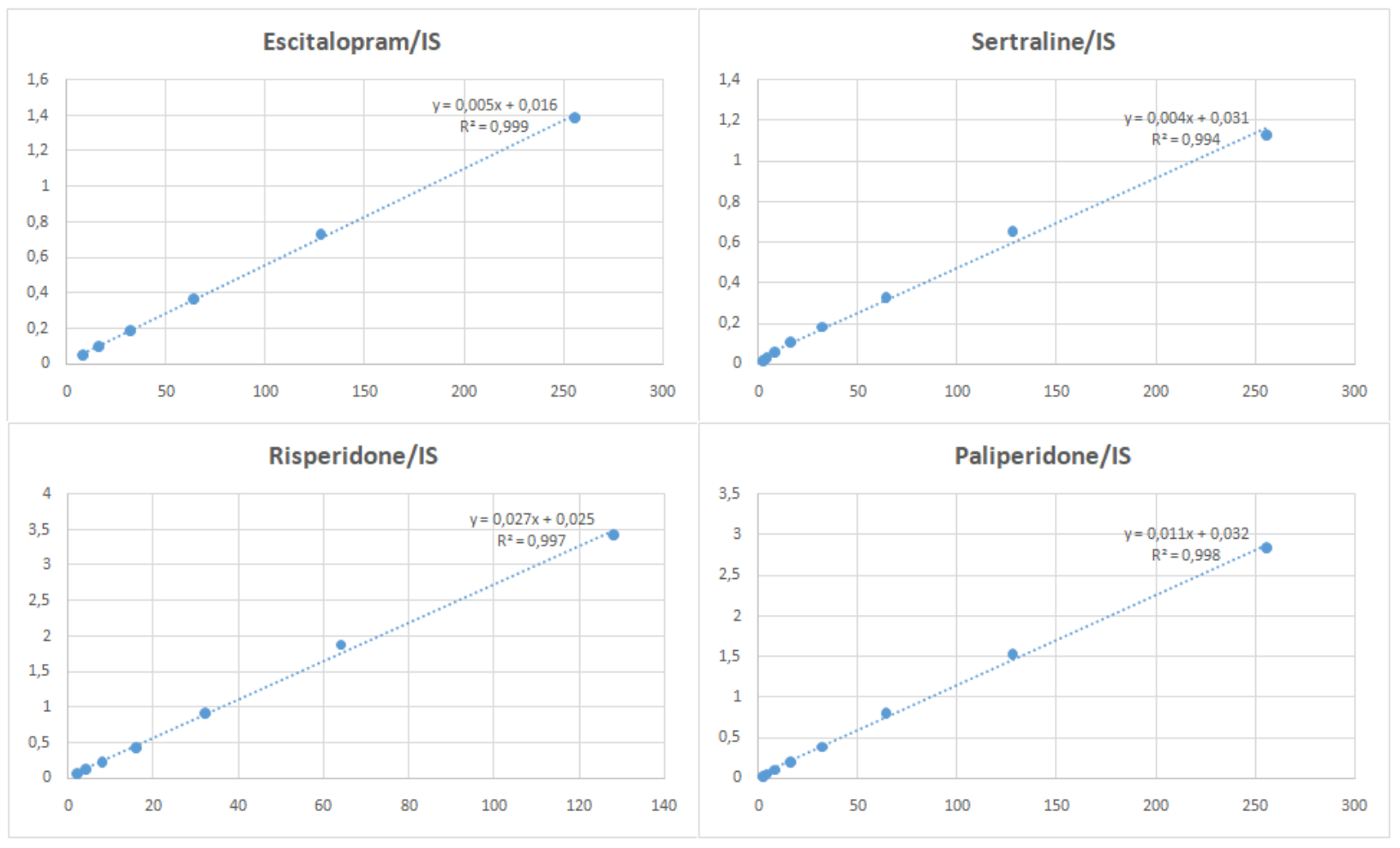

Figure 3. Linearity of calibration curves. Nominal concentrations are presented on the $x$-axis and peak areas of analyte harmonized by the peak area of the internal standard are presented on the y-axis for each of the analyzed drugs. Regression equations with coefficients of determination are presented in the higher right corner of each respective graph

Slika 3. Linearnost kalibracionih krivih. Zadate koncentracije se nalaze na $x-o s i$, a zapremina ispod krive analita harmonizovana na zapreminu ispod krive internog standard se nalazi na y-osi za svaku od analiziranih supstanci. Jednačine regresije sa koeficijentima determinacije se nalaze u gornjem desnom uglu svakog od grafika 
Table II Accuracy and precision analysis. CV - coefficient of variance, RE - Relative error i.e. difference between nominal and measured concentration divided by nominal concentration

Tabela II Tačnost i preciznost analize. CV- koeficijent varijacije, RE - Relativna greška, odnosno razlika između zadate i izmerene koncentracije harmonizovana na vrednost zadate koncentracije

\begin{tabular}{|c|c|c|c|c|}
\hline \multirow{4}{*}{ ESC } & $\begin{array}{c}\text { Nominal } \\
\text { concentration } \\
(\mathrm{ng} / \mathrm{ml})\end{array}$ & $\begin{array}{c}\text { Mean measured } \\
\text { concentration } \\
(\mathrm{ng} / \mathrm{ml})\end{array}$ & $\mathrm{CV}(\%)$ & $\mathrm{RE}(\%)$ \\
\cline { 2 - 5 } & 15 & 14.38 & 6.1 & -4.1 \\
\cline { 2 - 5 } & 40 & 36.63 & 3.5 & -8.4 \\
\hline \multirow{4}{*}{ SERT } & 80 & 76.86 & 6.2 & -3.1 \\
\cline { 2 - 5 } & 10 & 9.38 & 11.9 & -6.2 \\
\cline { 2 - 5 } & 150 & 43.02 & 4.2 & -14.0 \\
\hline \multirow{4}{*}{ RISP } & 10 & 146.44 & 5.4 & -2.4 \\
\cline { 2 - 5 } & 25 & 9.03 & 5.1 & -9.7 \\
\cline { 2 - 5 } & 60 & 22.11 & 2.7 & -11.6 \\
\hline \multirow{4}{*}{ PALI } & 10 & 51.53 & 3.8 & -14.1 \\
\cline { 2 - 5 } & 25 & 9.30 & 3.3 & -7.0 \\
\cline { 2 - 5 } & 60 & 24.96 & 4.5 & -0.2 \\
\hline
\end{tabular}

Measuring the concentration of several drugs simultaneously from the same sample is very important, knowing that a large number of patients use multiple psychiatric drugs. The HPLC-MS/MS method for simultaneous determination of sertraline, escitalopram, risperidone and paliperidone in human plasma was validated with respect to selectivity, linearity, accuracy, precision, matrix effect and stability. and it can be applied to support pharmacokinetic and clinical studies. The method has significant advantages in terms of low sample volume requirements $(200 \mu 1)$, short runtime (4 min per sample), and short preparation time (around three hours in total). The sample preparation procedure is designed as a pragmatic compromise between simplicity and efficiency, which is of critical importance for the analysis utilization possibilities. The method is suitably sensitive to cover low therapeutic concentrations, as well as toxic concentrations and therefore it can be successfully introduced into routine clinical practice for the purpose of therapeutic drug monitoring (TDM). 


\section{CONCLUSION}

This paper presents a quantitative methodology for sertraline, escitalopram, risperidone and paliperidone in a small sample volume of $0.2 \mathrm{~mL}$ of plasma. Sample preparation is quick and straightforward, which facilitates the application in clinical practice. The developed method represents a substantial advancement in process optimization compared with the previously published analytical protocols since it: (1) maintains sufficient precision and sensitivity for the clinically relevant drug level detection and clinical dosing decisions guidance, (2) shortens the time between blood harvesting and obtaining the results, (3) simplifies the sample preparation and provides the possibility of automatization.

\section{ACKNOWLEDGEMENTS}

This work has been financially supported by the Science Fund of the Republic of Serbia (PROMIS-PsyCise grant ID 6066800 to Marin Jukić, Filip Milosavljević, Aleksandra Jeremić, Bojan Marković, and Bojan Batinić). We thank undergraduate University of Belgrade - Faculty of Pharmacy students Andrea Atanasov, Isidora Kosmajac, Marina Manojlović, and Nikola Ašujić for their assistance with the experiments.

\section{REFERENCES}

1. Kessler RC, Wang PS. The descriptive epidemiology of commonly occurring mental disorders in the United States. Annu Rev Public Health. 2008;29:115-29.

2. Leucht S, Crippa A, Siafis S, Patel MX, Orsini N, Davis JM. Dose-response meta-analysis of antipsychotic drugs for acute schizophrenia. Am J Psychiatry. 2020;177(4):342-53.

3. Leucht S, Cipriani A, Spineli L, Mavridis D, Orey D, Richter F, et al. Comparative efficacy and tolerability of 15 antipsychotic drugs in schizophrenia: a multiple-treatments meta-analysis. Lancet. 2013; 382(9896):951-62.

4. Milosavljevic F, Bukvic N, Pavlovic Z, Miljevic C, Pešic V, Molden E, et al. Association of CYP2C19 and CYP2D6 Poor and Intermediate Metabolizer Status With Antidepressant and Antipsychotic Exposure: A Systematic Review and Meta-analysis. JAMA Psychiatry. doi:10.1001/jamapsychiatry.2020.3643.

5. Heimke C. Concentration-Effect Relationships of Psychoactive Drugs and the Problem to Calculate Therapeutic Reference Ranges. Ther Drug Monit. 2019;41(2):174-9.

6. Jukic MM, Haslemo T, Molden E, Ingelman-Sundberg M. Impact of CYP2C19 Genotype on Escitalopram Exposure and Therapeutic Failure: A Retrospective Study Based on 2,087 Patients.Am J Pcychiatry. 2018;175(5):463-70.

7. Bråten LS, Haslemo T, Jukic MM, Ingelman-Sundberg M, Molden E, Kringen MK. Impact of CYP2C19 genotype on sertraline exposure in 1200 Scandinavian patients. Neuropsychopharmacology. 2020;45(3):570-6. 
8. Jukic MM, Smith RL, Haslemo T, Molden E, Ingelman-Sundberg M. Effect of CYP2D6 genotype on exposure and efficacy of risperidone and aripiprazole: a retrospective, cohort study.Lancet Psychiatry. 2019;6(5):418-26.

9. Choong E, Rudaz S, Kottelat A, Guillarme D Veuthey JL Eap CB. Therapeutic drug monitoring of seven psychotropic drugs and four metabolites in human plasma by HPLC-MS. Pharm. Biomed. Anal. 2009;50(5):1000-8.

10. Kirchherr H, Kuhn-Velten WN. Quantitative determination of forty-eight antidepressants and antipsychotics in human serum by HPLC tandem mass spectrometry: a multi-level, single-sample approach. J Chromatogr B Analyt Technol Biomed Life Sci. 2006;843(1):100-13.

11. Juan H, Zhiling Z, Huande L. Simultaneous determination of fluoxetine, citalopram, paroxetine, venlafaxine in plasma by high performance liquid chromatography-electrospray ionization mass spectrometry (HPLC-MS/ESI). J Chromatogr B Analyt Technol Biomed Life Sci. 2005;820(1):33-9.

12. Zhou Z, Li X, Li K, Xie Z, Cheng Z, Peng W et al. Simultaneous determination of clozapine, olanzapine, risperidone and quetiapine in plasma by high-performance liquid chromatographyelectrospray ionization mass spectrometry J Chromatogr B Analyt Technol Biomed Life Sci. 2004;802(2):257-6.

13. Jiang KT, Rong Z, Peng L, Chen B, Xie Y, Chen C, et al. Simultaneous determination of citalopram and its metabolite in human plasma by LC-MS/MS applied to pharmacokinetic study. Journal of Chromatography B. 2010;878(5-6):615-9. 


\title{
Validacija brze i jednostavne hromatografske metode za simultanu kvantifikaciju nivoa sertralina, escitaloprama, risperidona i paliperidona u humanoj plazmi
}

\author{
Aleksandra Jeremić ${ }^{1 *}$, Filip Milosavljević ${ }^{1 *}$, Sandra Vladimirov ${ }^{2}$, \\ Bojan Batinić ${ }^{1}$, Bojan Marković ${ }^{3}$, Marin Jukić ${ }^{1,4 \#}$ \\ ${ }^{1}$ Univerzitet u Beogradu - Farmaceutski fakultet, Katedra za fiziologiju, \\ Beograd, Srbija \\ ${ }^{2}$ Univerzitet u Beogradu - Farmaceutski fakultet, Katedra za medicinsku biohemiju, \\ Beograd, Srbija \\ ${ }^{3}$ Univerzitet u Beogradu - Farmaceutski fakultet, Katedra za Farmaceutsku hemiju, \\ Beograd, Srbija \\ ${ }^{4}$ Farmakogenetski sektor, Katedra za fiziologiju i farmakologiju, Karolinska Institut, \\ Solna, Švedska
}

* Ovi autori su jednako doprineli originalnom naučnom radu i dele prvo autorstvo

\# Autor za korespondenciju: Marin Jukić,

E-mail: marin.jukic@pharmacy.bg.ac.rs ili marin.jukic@ki.se

\begin{abstract}
KRATAK SADRŽAJ
Simultana kvantifikacija većeg broja psihijatrijskih lekova je važna za terapijsko praćenje psihijatrijskih pacijenata. Takođe, od značaja iz praktičnih razloga bi bilo da metoda bude jednostavna, laka za izvođenje i da ne zahteva puno vremena. Uzorak plazme $(200 \mu \mathrm{l})$ je deproteinizovan i izvršeno je hromatografsko razdvajanje lekova na ZORBAX Eclipse XDBPhenyl koloni sa mobilnom fazom sačinjenom od acetonitrila $\mathbf{i}$ vodenog rastvora $0,1 \%$ mravlje kiseline (60:40, v/v). Maseni spektri snimani su u MRM modu korišćenjem izvora sa elektrosprej pozitivnom jonizacijom i tandemske masene detekcije. Ispitivani opseg koncentracija bio je $2-256 \mathrm{ng} / \mathrm{ml}$ za sve analizirane lekove, osim za escitalopram, gde je bio 8-256 ng/ml. Kontrolni uzorci su pripremani u kvintuplikatu u tri relevantne koncentracije za svaki lek. Determinacioni koeficijenti $\left(\mathrm{R}^{2}\right)$ bili su veći od 0,99 , dok su relativna razlika između nominalnih i merenih koncentracija (RV) i koeficijent varijacije (CV) bili manji od $15 \%$ za sve analite. Metoda tečne hromatografije visokih performansi uparena sa tandem masenim detektorom (HPLC-MS/MS) je validirana u pogledu selektivnosti, linearnosti, tačnosti, preciznosti, efekata matriksa i stabilnosti za simultano određivanje sertralina, escitaloprama, risperidona i paliperidona u humanoj plazmi. Metoda zahteva malu zapreminu uzorka (200 $\mu 1)$, kratke pripreme uzorka (3 sata) i kratko vreme trajanja pojedinačnog merenja (4 minuta).
\end{abstract}

Ključne reči: sertralin, escitalopram, risperidon, paliperidon, HPLC-MS/MS 